\title{
A Theoretical Framework for Designing Smart and Ubiquitous Learning Environments for Outdoor Cultural Heritage
}

\author{
Alaa Alkhafaji ${ }^{a, c}$ Sanaz Fallahkhair ${ }^{b}$ Ella Haig ${ }^{a}$ \\ ${ }^{a}$ School of Computing, University of Portsmouth, Portsmouth, UK \\ ${ }^{\mathrm{b}}$ School of Computing, University of Brighton, Brighton UK \\ ${ }^{c}$ Department of Computer Science, College of Science, Mustansiriyah University, Baghdad, Iraq
}

\begin{abstract}
Cultural heritage is constantly attracting researchers and developers to introduce services that could support informal learning and enhance visitors' experience at sites, through the use of technology. Few studies introduced models and frameworks for developing learning technologies, however, none of them were developed for supporting informal learning on-themove at outdoor cultural heritage. This paper introduces a theoretical Framework for designing Smart and ubiquitous Learning Environments (FoSLE) for outdoor cultural heritage sites, which was formulated based on the results of three field studies that were conducted for gathering user requirements. A user-centred design approach using sequential mixed methods was adopted with data being gathered using focus group, questionnaire and interview techniques. A set of general requirements was extracted from the framework to inform the design of a smart and ubiquitous learning environment proof-of-concept, SmartC, for which mobile and wearable technologies were utilised.
\end{abstract}

Keywords: ubiquitous learning, mobile and wearable technologies, mixed methods approach, user-centred design, cultural heritage.

\section{Introduction}

Cultural heritage is constantly attracting researchers and developers to introduce new technologies that could enhance visitors' experience at sites, as well as enhance the sites' interpretation, which in turn enhances informal learning from sites. Learning at sites, which is a significant facet of informal learning, might require visitors to move from one attraction to another in order to read the provided information. Ubiquitous learning (u-learning) with the harnessing of mobile and wearable technologies would support visitors learn on-the-move at sites[1], which frees visitors from the boundaries of time and place [2]. U-learning offers the foundation for the concept of smart learning environment as it gives people the opportunity to learn within different contexts while doing daily activities [3]. The smart learning environment 
concept refers to the acquisition of information about the learners and their surrounding environment intelligently to enhance people' experience [4]. Thus, it would be a great support for visitors of cultural heritage as it would help them receive information regarding the surrounding cultural heritage places while they are walking at sites, which would promote the concept of informal learning where learners are in charge of their learning instead of being content consumers.

As encouraging people to learn is challenging especially if it takes the form of informal learning [5], researchers are constantly seeking ways to introduce services that help make the learning process more enjoyable, engaging and could be adaptable to users' needs [6]. That, in turn, would enhance users' engagement and satisfaction [7], which is especially important for enhancing engagements and experience of visitors at cultural heritage sites as people often see it as a form of entertainment [8]. In this context, designing technologies that draw users' interest for learning at sites is challenging since learners have different characteristics and preferences, which requires services need to be adapted based on them $[9,10]$. Thus, it is essential to involve learners/visitors in designing such technologies to help capture user requirements [11]. This would help prevent major issues in the design that may delay the delivery of productsas [1214]. In addition, it is also important to introduce tools that assist researchers in designing learning technologies and guide the design to meet users' needs and preferences, which would help feature adaptive learning services; that would enhance satisfaction as well as learning from sites.

The context of cultural heritage might have different requirements than other contexts, as often the visit to sites is considered as an entertainment trip not learning as we mentioned. Thus, it is essential to enhance visitors' engagements, which would motivate visitors to take learning opportunities at sites. Additionally, the outdoor settings of sites have special requirements, where variables such as weather and level of brightness (i.e. sun light), are not easy to control and at the same time enhance engagement. Hence, there is a need to introduce a tool that considers these variables based on user' perspectives, which has not been given a great attention in the literature (see Section 2).

While a number of frameworks have been proposed for informal learning such as in [1517] and new technologies have been developed for cultural heritage such as in [18, 19], none of these were developed for supporting informal learning at outdoor cultural heritage sites and on-the-move, while also considering users' requirements. Designing such services that meet learners/visitors' needs would be essential to enhance their engagement at sites as visitors do not consider visiting outdoors cultural heritage sites as a form of learning, but rather as a form 
of entertainment. Some studies were conducted with respect to cultural heritage sites but not necessarily for outdoors [20-26]. Immersive technologies such as augmented and virtual reality (AR \& VR), and gamification were also harnessed to enhance the experience of sites for instance in [27-34]. However, they were not dedicated for introducing a framework for enhancing learning experience from sites on-the-move.

This paper introduces a theoretical framework for designing smart and ubiquitous learning environments (FoSLE) for outdoor cultural heritage, which considered learners/visitors' requirements. FoSLE was formulated based on three field studies that were carried out to gather user requirements with the aim of identifying the essential elements for designing technologies that support informal learning at sites as well as enhance visitors' engagements and experience as well as sites' interpretation. This framework was designed to assist researchers who work in the field of technology enhanced visitors' experience as well as sites' interpretation in designing such services. FoSLE harnessed mobile and immersive technologies (i.e. smart eye glasses and AR) with the aim of enhancing visitors' engagement as AR would be an excellent choice for drawing visitors' interest as well as contribute to a better interpretation of sites $[25,26]$. FoSLE consists of six broad categories, which are: Learner, content, learning design, interaction design, context and, challenges and obstacles. A set of general requirements was drawn out from the framework to inform the design of a proofof-concept.

The rest of the paper is structured as follows: section 2 discusses theories of use that were involved in designing the framework; section 3 gives an overview of previous models and frameworks that support informal learning and/or learning at cultural heritage sites; setion 4 presents the aim and objectives of the research; section 5 discusses the methodology adopted in this research; section 6 presents the findings, which is the FoSLE framework; section 7 presents the development of the proof-of-concept mobile app; section 8 discusses and highligts the findings and the main contribution of this research; section 9 concludes the paper and provides a direction for future work. The next section gives an overview of theories involved in designing the framework alongside the field studies.

\section{Theories of Use}

Ubiquitous computing offers technology that interweaves into our lives and the surrounded environment in an unobtrusive way [35], which was harnessed in the field of learning to enhance learning experiences. Ubiquitous computing referes to embedding computers invisibly into our daily life [36]. Thus, learning has become ubiquitous with 
harnessing mobile and wearable technologies [2], which support learning in both formal and informal contexts $[37,38]$. Ubiquitous learning (u-learning) promises to free people from the boundaries of time and place, providing opportunities for people to learn regardless of where they physically are using mobile and wearable technologies [39], which would be a great support for informal learning.

The informal learning concept has been increasingly used in adult education [40]. It refers to learning when it occurs out of the formal education context in which learners take the active role and are being in charge of their learning. It could be considered the complimentary partner to the experiential learning [40]. Kolb defines learning as " ...the process whereby knowledge is created through the transformation of experience" [41]. Individuals learn when experiencing life and through a trial and error process, which often happens incidentally and spontaneously [42].

The learning from experience notion was originally developed by the theorist John Dewey (Dewey 1938), which served as the foundation stone for developing the concept of informal learning. Learning happens during social life, when individuals are interacting with the community, as social learning involves supporting learning via observing others' behaviours, attitudes and cognitive processes [43, 44]. In other words, learning occurs by engaging with the community while doing formal or informal activities. In the same vein, collaborative learning is an approach of learning that involves learning by sharing experiences between learners, which also could be considered as social learning [45]. Learning occurs at any time and place, as there is no restriction for acquiring information and enhancing knowledge, which supports situated learning.

Lave and Wenger [46] argue that situated learning is the acquisition of knowledge through a community of practice where social interaction in context is the main component of the learning process. Conversation tends to enhance memory and consequently enhance learning as the discussed information meant to stay longer in an individual's memory [47]. Pask [48] defines conversational learning as "conversational systems which allow mental activities to be described in terms of dialogue and behaviour" [48]. Conversation helps construct knowledge between learners, which in turn enhances their knowledge [49]. Thus, interacting and socialising with the community would enhance informal learning as people could reinforce their knowledge by sharing their experience with each other's [44].

The aforementioned theories helped in designing the proposed framework, the corresponding theory will be mention where appropriate (see Table 2). The next section provides an overview of the frameworks and models that support informal/non-formal learning. 


\section{Frameworks and Models to Support Informal Learning}

In recent years, there has been an increase interest in the literature regarding informal learning. Various issues within informal learning have attracted the attention of researchers. A number of studies have been conducted in the field of informal learning that have developed models and frameworks for learning throughout a lifetime. Some studies also focused on cultural heritage. Previous studies related to models/frameworks for informal learning are listed in Table 1.

Several researchers looked into the development of services that support learning at cultural heritage sites for both formal/non-formal $[18,19,50,51]$ and informal learning [4, 52-54]. These were developed for particular goals, e.g. formal learning for field trips [3] or a particular site $[55,56]$. These works, however, did not focus on the development of a framework or model, and consequently, were not included in Table 1; see Abbrivation for clarification .

\begin{tabular}{l|l}
\hline For new technology & $\mathrm{NT}$ \\
\hline Model/framework & $\mathrm{M} / \mathrm{F}$ \\
\hline Field/Context & $\mathrm{F} / \mathrm{C}$ \\
\hline Theories/methods applied & $\mathrm{T} / \mathrm{M}$ \\
\hline User-centred design & $\mathrm{UCD}$ \\
\hline & $\begin{array}{l}\text { Indicates the } \\
\text { study supports what } \\
\text { is being said in the } \\
\text { title of the column }\end{array}$ \\
\hline
\end{tabular}

Table 1. Previous models/frameworks that support informal learning

\begin{tabular}{|c|c|c|c|c|c|}
\hline Author(s) & NT & $\mathrm{M} / \mathrm{F}$ & $\mathrm{F} / \mathrm{C}$ & $\mathrm{T} / \mathrm{M}$ & $\mathrm{UC}$ \\
\hline $\begin{array}{l}\text { Marsick and Watkins } \\
{[15]}\end{array}$ & & $\begin{array}{l}\text { Informal and incidental } \\
\text { learning model }\end{array}$ & $\begin{array}{l}\text { Informal learning in } \\
\text { workplace }\end{array}$ & $\begin{array}{l}\text { Dewey's work/ } \\
\text { a previous study }\end{array}$ & \\
\hline Vavoula [57] & $\mathrm{X}$ & $\begin{array}{l}\text { FoLL: a framework of } \\
\text { lifelong learning }\end{array}$ & Lifelong learning & $\begin{array}{l}\text { Diary and } \\
\text { interviews }\end{array}$ & $X$ \\
\hline Bagnasco, et al. [58] & $\mathrm{X}$ & $\begin{array}{l}\text { A virtual learning } \\
\text { community / Online } \\
\text { classroom }\end{array}$ & $\begin{array}{l}\text { e-training environment } \\
\text { in workplace/ just-in- } \\
\text { time }\end{array}$ & \begin{tabular}{|l} 
Does not \\
mention, seems \\
to be based on \\
previous studies
\end{tabular} & \\
\hline $\begin{array}{l}\text { Pemberton, et al. } \\
\text { [59] }\end{array}$ & $\mathrm{X}$ & $\begin{array}{l}\text { A pedagogical framework } \\
\text { for informal language }\end{array}$ & $\begin{array}{l}\text { Informal language } \\
\text { learning }\end{array}$ & $\begin{array}{l}\text { Based on the } \\
\text { review of }\end{array}$ & $X$ \\
\hline
\end{tabular}




\begin{tabular}{|c|c|c|c|c|c|}
\hline & & $\begin{array}{l}\text { learning services via } \\
\text { interactive television }\end{array}$ & & $\begin{array}{l}\text { previous models } \\
\text { and focus group } \\
\text { studies }\end{array}$ & \\
\hline Koper, et al. [16] & & $\begin{array}{l}\text { A design model for } \\
\text { lifelong learning } \\
\text { networks }\end{array}$ & Informal learning & Theory-based & \\
\hline Li, et al. [60] & $\mathrm{X}$ & $\begin{array}{l}\text { A conceptual framework } \\
\text { of computer-supported } \\
\text { Ubiquitous learning } \\
\text { environment (ULE) }\end{array}$ & $\begin{array}{l}\text { ULE is for integrating } \\
\text { schools, communities, } \\
\text { and families. }\end{array}$ & Theory-based & \\
\hline Zhang, et al. [61] & $\mathrm{X}$ & $\begin{array}{l}\text { A Framework of Social } \\
\text { Interaction Support for } \\
\text { Ubiquitous Learning }\end{array}$ & $\begin{array}{l}\text { A social interaction } \\
\text { community }\end{array}$ & Theory-based & \\
\hline Taylor, et al. [62] & $\mathrm{X}$ & $\begin{array}{l}\text { Task Model for Mobile } \\
\text { Learning }\end{array}$ & Mobile learning & $\begin{array}{l}\text { Two field } \\
\text { studies }\end{array}$ & $\mathrm{X}$ \\
\hline Nino, et al. [63] & $\mathrm{X}$ & $\begin{array}{l}\text { Context-Aware Model for } \\
\text { Ubiquitous Learning } \\
\text { Environment }\end{array}$ & Ubiquitous Learning & Previous studies & \\
\hline De Jong, et al. [64] & & $\begin{array}{l}\text { Reference model (content, } \\
\text { context, purpose, } \\
\text { information flow } \\
\text { and pedagogical model) }\end{array}$ & $\begin{array}{l}\text { Learning, mobile social } \\
\text { software }\end{array}$ & Previous studies & \\
\hline Saccol, et al. [65] & $\mathrm{X}$ & $\begin{array}{l}\text { A framework for the } \\
\text { design of ubiquitous } \\
\text { learning applications }\end{array}$ & $\begin{array}{l}\text { Ubiquitous learning/ } \\
\text { learning in general }\end{array}$ & \begin{tabular}{|l} 
Literature/ \\
previous studies
\end{tabular} & \\
\hline Chatti, et al. [66] & & 3P learning model for TEL & $\begin{array}{l}\text { Informal, lifelong } \\
\text { learning }\end{array}$ & $\begin{array}{l}\text { Does not } \\
\text { mention, seems } \\
\text { to be based on } \\
\text { literature }\end{array}$ & \\
\hline Barbosa, et al. [67] & $\mathrm{X}$ & $\begin{array}{l}\text { A ubiquitous learning } \\
\text { model focused on learner } \\
\text { interaction (LOCAL) }\end{array}$ & Ubiquitous learning & $\begin{array}{l}\text { A previous } \\
\text { study (Saccol et } \\
\text { al., 2009) }\end{array}$ & \\
\hline
\end{tabular}




\begin{tabular}{|c|c|c|c|c|c|}
\hline FitzGerald [17] & & $\begin{array}{l}\text { Creating user-generated } \\
\text { content for location based } \\
\text { learning: an authoring } \\
\text { framework }\end{array}$ & Informal learning & Literature-based & \\
\hline Park, et al. [68] & & $\begin{array}{l}\text { Task Model and Task } \\
\text { Ontology for Intelligent } \\
\text { Tourist Information } \\
\text { Service }\end{array}$ & Tourism & Case study & $X$ \\
\hline Candello [69] & & $\begin{array}{l}\text { Framework for content } \\
\text { presentation in outdoor } \\
\text { settings }\end{array}$ & $\begin{array}{l}\text { Tourism/Informal } \\
\text { learning } \\
\text { Outdoor cultural } \\
\text { heritage }\end{array}$ & $\begin{array}{l}\text { Observations, } \\
\text { interviews and } \\
\text { questionnaire }\end{array}$ & $\mathrm{X}$ \\
\hline Yin, et al. [70] & & Conceptual framework & $\begin{array}{l}\text { Scaffolding } \\
\text { participatory simulation } \\
\text { for mobile learning }\end{array}$ & $\begin{array}{l}\text { Based on } \\
\text { experiential } \\
\text { learning theory }\end{array}$ & \\
\hline Saeed, et al. [71] & & $\begin{array}{l}\text { Framework for interactive } \\
\text { mobile application } \\
\text { (usability framework) }\end{array}$ & $\begin{array}{l}\text { Mobile application in } \\
\text { general, smartphone }\end{array}$ & $\begin{array}{l}\text { Observations } \\
\text { and interviews } \\
\text { Evaluation/ } \\
\text { usability test }\end{array}$ & $\mathrm{X}$ \\
\hline Hwang [3] & $\mathrm{X}$ & $\begin{array}{l}\text { Framework for smart } \\
\text { learning environments }\end{array}$ & $\begin{array}{l}\text { Real-world and online } \\
\text { contexts (non-formal) }\end{array}$ & Literature & \\
\hline $\begin{array}{l}\text { Koren and Klamma } \\
\text { [25] }\end{array}$ & & $\begin{array}{l}\text { A framework for dealing } \\
\text { with physical artefacts } \\
\text { using wearable computing }\end{array}$ & Informal learning & $\begin{array}{l}\text { Previous } \\
\text { projects }\end{array}$ & \\
\hline $\begin{array}{l}\text { Aziz \& Khoukhi, } \\
\text { (2017) }\end{array}$ & & $\begin{array}{l}\text { A Design Requirements } \\
\text { Framework for Mobile } \\
\text { Learning Environment }\end{array}$ & $\begin{array}{l}\text { Mobile learning/formal } \\
\text { and informal learning }\end{array}$ & $\begin{array}{l}\text { Learning } \\
\text { theories }\end{array}$ & \\
\hline $\begin{array}{l}\text { Parsazadeh, et al. } \\
{[72]}\end{array}$ & & $\begin{array}{l}\text { A framework for } \\
\text { cooperative and interactive } \\
\text { mobile learning to } \\
\text { improver online } \\
\text { information evaluation } \\
\text { skills }\end{array}$ & Mobile online learning & $\begin{array}{l}\text { previous } \\
\text { research, the } \\
\text { cooperative } \\
\text { learning model, } \\
\text { and interactive } \\
\text { learning theory. }\end{array}$ & \\
\hline Ada [73] & & $\begin{array}{l}\text { Using design-based } \\
\text { research to develop a }\end{array}$ & $\begin{array}{l}\text { Formal learning/ } \\
\text { Assessment feedback }\end{array}$ & Observations & $\mathrm{X}$ \\
\hline
\end{tabular}




\begin{tabular}{|l|l|l|l|l|}
\hline & $\begin{array}{l}\text { Mobile Learning } \\
\text { Framework for } \\
\text { Assessment } \\
\text { Feedback }\end{array}$ & & & \\
\hline
\end{tabular}

As it is shown in Table 1, some of the presented models were introduced to support designing new technologies [3, 57, 61-63, 65, 67, 74], however, four of them, Vavoula, Pemberton et al., Taylor et al.'s and Candello's models have considered user requirements in designing the corresponding model/framework, only Candello's one was introduced for cultural heritage context. Considering user requirements in designing new technologies is an essential element in enhancing visitors' engagement as it would provide an adaptive learning environment based on visitors' preferences.

The learning experience at cultural heritage sites requires visitors to move around sites and get close to attractions in order to read the available information and also it is often not as quiet as other learning environments. In addition, the visit of outdoor cultural heritage settings involves different contexts as visitors visit with family and friends or on their own. Moreover, different reasons drive them to visit, such as for getting their children to learn their history, which need to be taken into account when designing new technologies.

An important aspect in the cultural heritage context is the necessity of enhancing visitors' engagement to take this experience, as well as enhance the interpretation of sites. Interpretation is not only presenting factual information but more importantly evoking the emotional and intellectual connection between visitors and attractions [75]. That in turn, would promote the sense of loyalty and belonging to the community as well as increase awareness of cultural heritage places, which consequently would encourage the preservation of sites. In addition, due to the fact that visitors need to go elsewhere after the visit, investing the time smartly during the visits is crucial. Given that, technologies for cultural heritage contexts need some extra aspects to be considered, which were not considered in the mentioned frameworks and models, such as: (a) the content that learners/visitors consume to perceive history; and (b) interaction with the contexts, which could involve some important aspects such as: activities that visitors perform to take learning opportunities, resources and tools that mediated the performance, information format, and, the interface design that learners use to access services and activities.

Besides the aforementioned studies, some other were introduced for cultural spaces but not necessarily for outdoors, as mentioned earlier; they were not dedicated for introducing a framework for enhancing learning from sites [20-25, 76, 77]. However, non of them was for 
designing a smart environment to support learning on-the-move at outdoor cultural heritage sites.

The research reported in this paper investigated how people would use ubiquitous technology at cultural heritage sites and how technology can support learning at sites. The socio-cognitive engineering methodology [78] was used, which allowed the integration between the field studies and the corresponding learning theories to define a task model, i.e. the FoSLE framework. The field studies provided information about how users use ubiquitous technology at cultural sites, as well as how they would like technology to support their experience at the sites. The FoSLE framework provides information for researchers and designers to assist them in designing new technologies for supporting informal learning at outdoor cultural heritage sites. The FoSLE framework was developed to address the characteristics of the outdoor cultural heritage context by considering users' requirements. The next section gives an overview of the aim and objectives of the research.

\section{The Aim and Objective of this Research}

This research aims to explore and develop the potential of ubiquitous technologies for cultural heritage. This research has investigated how people may use mobile and wearable technologies for learning purposes, and also how ubiquitous learning environments could be developed based on mobile and wearable technologies to support informal learning in cultural heritage contexts. This research aims to achieve a number of objectives, which include:

1. To develop a task model in the form of a theoretical framework for smart and ubiquitous learning environments utilising mobile location-based services to be used at outdoor cultural heritage sites.

2. To develop a smart and ubiquitous learning environment utilising mobile and wearable technologies as a proof-of-concept based on the task model.

The starting point of this research is triggered by the following questions:

1. How do people use ubiquitous technologies for learning purposes at cultural heritage sites?

2. What are the essential elements for developing a smart and ubiquitous learning environment utilising mobile and wearable technologies for cultural heritage sites that meets the user's needs?

The next section gives an overview of the methodology, methods and techniques adopted to answer the questions and reach the aim. 


\section{Methodology}

A user-centred design approach was used, using an adapted version of the socio-cognitive engineering methodology (SCE) [78] to help answering the research questions.

SCE consists of two main stages, analysis and design, that are connected in an intermediate stage bridging the two main stages, i.e. the task model. Each stage involves a number of elements or sub-stages to achieve a specific goal (see Figure 1). The analysis stage has two elements, field studies and theory of use. The field studies involve investigating people's behaviours, attitudes and habits regarding the investigated activities, while the theory of use involves studying theories related to these activities, which was explainded in Section 2 and will be mentioned where appropriate when presenting the framework in Section 6 . These two elements are pulled together to formulate a task model, which bridges the analysis stage with the design stage in an iterative manner and provides a set of principles in the form of requirements that could be adopted to inform designing new artefacts.

The focus of this paper is on the analysis stage, which led to the development of the FoSLE framework. To illustrate how the framework could be used, we present a proof-of-concept with features drawn from the framework in section 7; however, we do not go into details, as the process of developing the proof-of-concept is out of the scope of this paper.

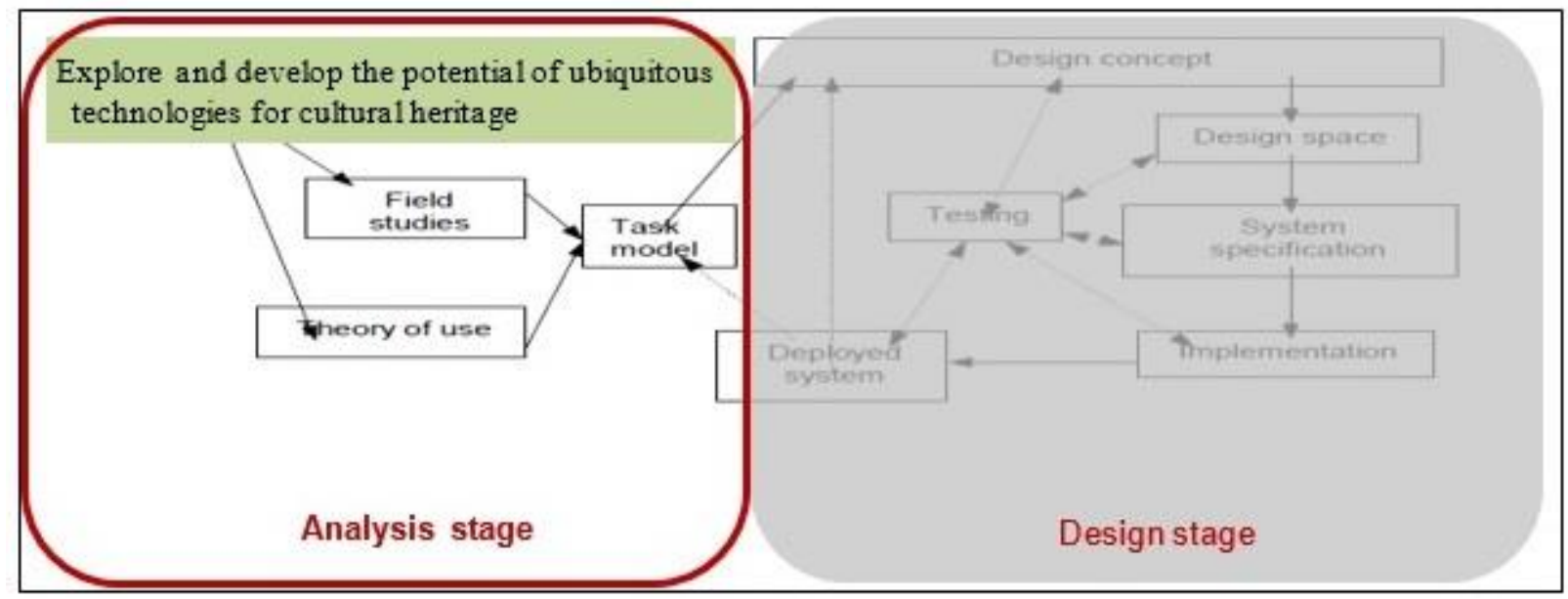

Figure 1. The adapted version of the socio-cognitive engineering (SCE) methodology [76]; the grayed area is not discussed in this paper.

Three empirical studies were conducted sequentially using mixed methods with data being gathered using focus group, questionnaire and interview techniques [79]. This approach was used to combine different methods (quantitative and qualitative) to gain a better insight regarding the investigated aspects as each one could overcome the limitation of the other. 
Additionally, it involves end users in the design process, which has the benefit of designing a tool based on their perspectives and consequentely it could meet their needs. This would significantely benefit adaptive learning. The studies were integrated during the interpretation of the results of the field studies. As we pointed earlier a theoretical framework (FoSLE) has been devised from the field studies and the learning theories that were presented in Section 2 (see Figure 3); details of each study are given in this section. A set of general requirements was pulled out from the framework to guide the design of a proof-of concept; Figure 2 illustrates the steps of the research.

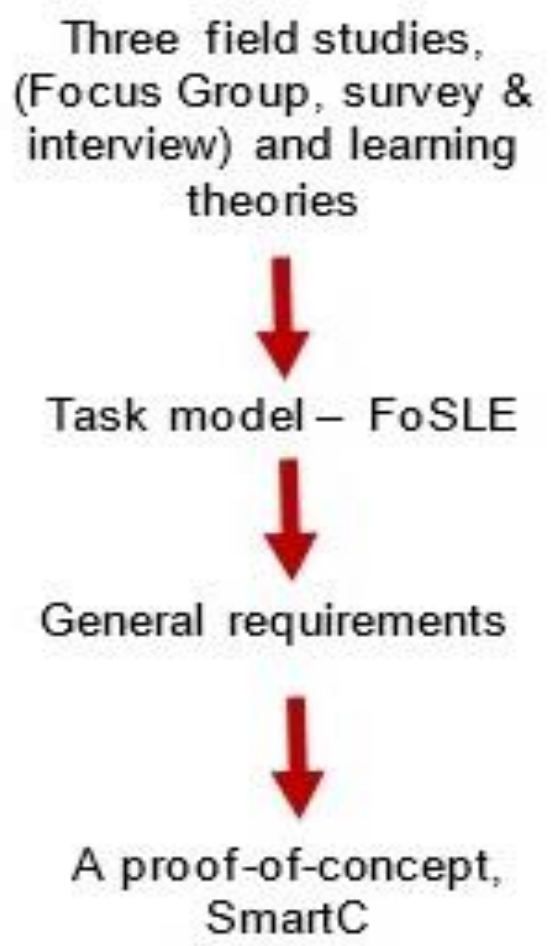

Figure 2. Illustration of the research steps 


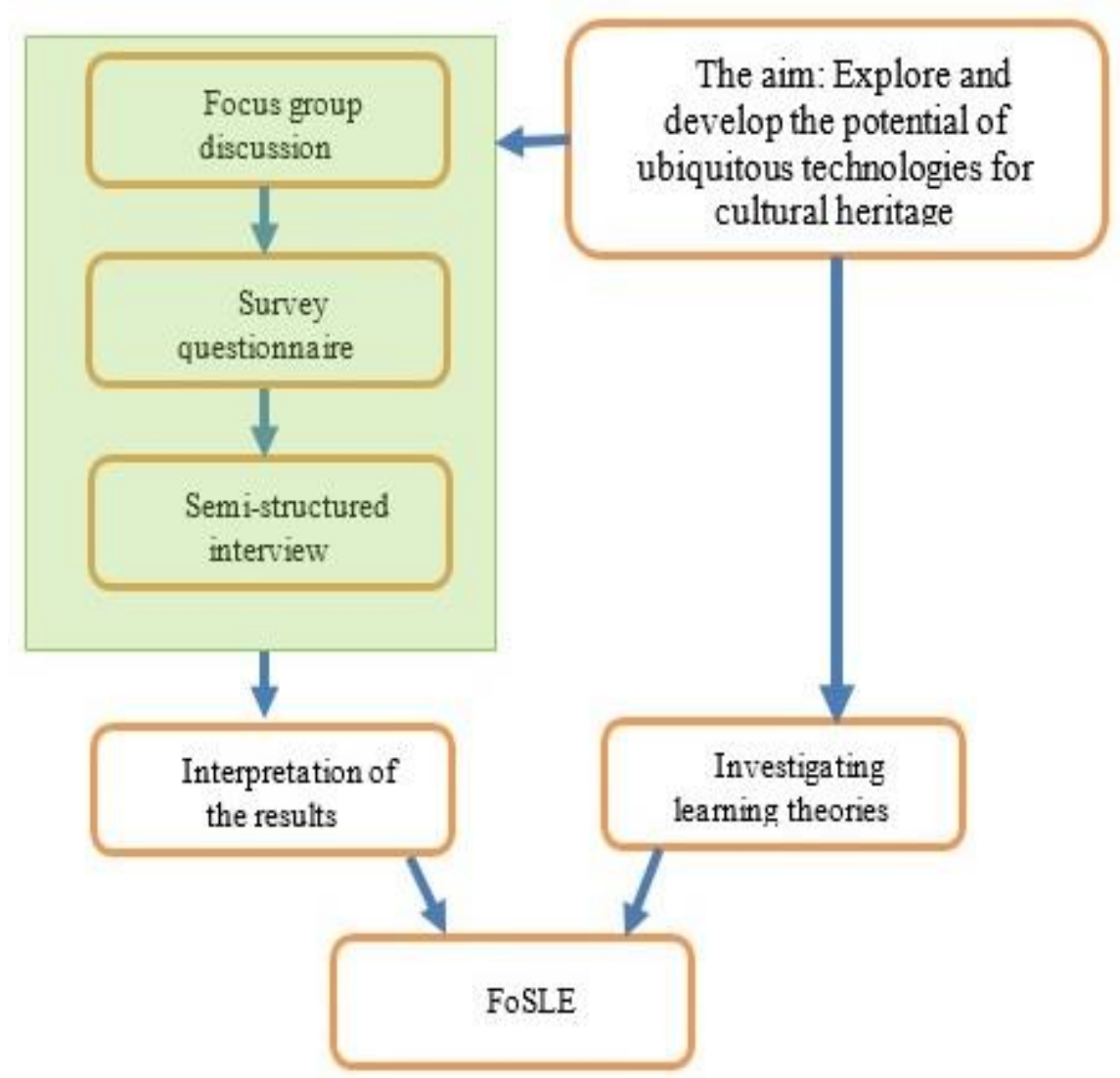

Figure 3: The process of collecting data and formulating the framework

\subsection{The focus Group Study}

A focus group discussion was carried out to extract users' perspectives regarding the use of mobile technology for learning purposes. Six broad themes resulted from the study, which are: Learners and Devices, The Notion of Learning, Motivation and Attitude, Services and Features, Information, Usability, Acceptance and Usefulness, and Challenges and interventions. These themes helped to design a questionnaire for the next step of the research as well as carry out further research.

A focus group discussion [80-82] was carried out with the aim of gathering preliminary requirements to inform the questionnaire design. It was conducted at the University of Portsmouth; participants have been recruited amongst students' community of the University of Portsmouth. Ten people were invited to take part in this focus group study with the aim of recruiting as many participants as possible with diversity of different demographic background, six participants showed up on the day. A Doodle notification was sent to set a day/time that was suitable for everybody who was taking part, in order to organise the meeting; all of them were familiar with mobile technology. It is important to note that the sample selected for this study were chosen from different background to have a wide spectrum of opinions. Four pre- 
prepared questions have been asked, which are listed below. The discussion took around one hour and twenty minutes, and it was recorded, and afterward transcribed. The thematic analysis method was used to analyse the qualitative data [5].

1. Would you like to write down what comes up to mind when someone says using a mobile device at cultural heritage sites, (e.g. positive or negative aspects, services, environment, etc.).

This question were asked to find out how participants experience and use mobile devices at cultural heritage sites

2. How many of you are using a mobile device?

This question were asked to find out if participants actually use mobile devices

3. Are you using a mobile device for learning? Why?

This question were asked to find out if participants use mobile devices for learning and why

4. What do you think, why people would visit cultural heritage sites?

This question were asked to find out what is participants point of view of what could motivate people to visit sites

Six participants took part in this discussion; their age ranged from 28 to 50; three were males and three females; all of them were students. They were from different backgrounds: two English, two Arabic, one Nigerian, and one Indonesian. All of them were familiar with mobile technology and have used it for different purposes; however, they had different levels of interest in cultural heritage.

\subsection{The Survey Study}

A questionnaire technique was used to gather broad user requirements to investigate how people use mobile technology for learning purposes at outdoor cultural heritage sites. The questionnaire was designed based on themes that resulted from the focus group study. The questionnaire involved different sets of questions: multiple choices with one option, multiple choices with several options, and open-ended questions; online and paper-based questionnaires were used. The convenience method of sampling was used to recruit participants [83]. A simple statistical analysis was carried out to obtain frequencies of the nominal data using the SPSS software [84].

189 participants responded to this survey aged between 18 and $70+$ years. $47 \%$ of participants were male and $52 \%$ were female. The vast majority of participants (86\%) lived in 
the UK with the remainder in a number of locations. $47 \%$ of participants were students, $33 \%$ were employed and $12 \%$ were retired. The remainders were unemployed (4\%) and selfemployed (3\%). $3 \%$ of participants stated other occupations such as researcher, independent, and semi-retired. Some participants stated more than one occupation such as student and parttime employed at the same time, which explains why the total is more that $100 \%$. The results of this study contributed to design the next step, which is the interview study (see Appendix A).

\subsection{The Interview Study}

A semi-structured interview technique was used in this study to collect in-depth qualitative data regarding how people use mobile devices for learning at cultural heritage sites. The interview questions were designed based on the results of the survey study as they sugest that some aspects were not as popular, such as learning collaboratively and using wearable technologies, which needed to be investigated further (see Apppendix A). A convenience sampling method was used to recruit participants. An email was sent to each participant separately to state date/time to conduct the interview. The interviews were recorded; the duration ranged between 25 and 50 minutes.

Ten participants took part in this study; eight were end-users and two were staff members of cultural heritage. The end-users were aged between 28 and 70, two males and six females, all of them were interested in cultural heritage. The staff members worked at the Historic Dockyard in Portsmouth; they were interviewed to find out about their experience regarding how visitors use technology at their sites.

Next section presents the findings - the proposed framework, FoSLE

\section{The Results - The FoSLE Framework}

Based on the results of the field studies, a theoretical framework, FoSLE, was formulated for designing smart and ubiquitous learning environments (S-ULEs) for learning informally in cultural heritage contexts. Six broad categories were identified in the field studies: (1) learner; (2) content; (3) learning design; (4) interaction design; (5) contexts; (6) challenges and obstacles. 
This section discusses the categories based on the findings; a justification for each category with examples from the field studies and the learning theories are given in Table 2; details of each category are given in this section. It is important to highlight that some results from the field studies are consistent with the learning theories that were used in this research; for instance, in the "learning design" category there is an example from the interviews where participants highlighted that the conversation meant to boost their memory which is align with the conversation theory. The abbreviations used are: (1) Source (SC); (2) Focus group (FG) (3) Survey study (SS); (4) Interview study (IS); (5) Theory of use (ToU).

Table 2. categories of the FoSLE framework with justifications and examples from the field studies

\begin{tabular}{|c|c|c|c|}
\hline categories & Justification & Examples & $\mathrm{SC}$ \\
\hline \multirow{4}{*}{ Learner } & $\begin{array}{l}\text { Learners performs and } \\
\text { conceive learning differently }\end{array}$ & $\begin{array}{l}\text { "in addition to the constructs } \\
\text { of intelligence, and personality, } \\
\text { there is also cognitive style as a } \\
\text { distinct construct, and that style } \\
\text { is different in nature and in the } \\
\text { way it affects behaviour" [85]. }\end{array}$ & ToU \\
\hline & $\begin{array}{l}\text { Respondents stated they would } \\
\text { like to customise their app based } \\
\text { on their preferences }\end{array}$ & $\begin{array}{l}62 \% \text { of respondents ticked } \\
\text { "Yes" for customising their } \\
\text { app. }\end{array}$ & SS \\
\hline & \multirow[t]{2}{*}{$\begin{array}{l}\text { Participants emphasised that } \\
\text { people differ in their } \\
\text { characteristic, motivations and } \\
\text { habits }\end{array}$} & $\begin{array}{l}\text { "if you had like a particular } \\
\text { interest in certain aspects of the } \\
\text { site you can may be tailored to } \\
\text { that, you can select what things } \\
\text { are more interesting to you" }\end{array}$ & IS \\
\hline & & $\begin{array}{l}\text { "...different people has } \\
\text { different preference" }\end{array}$ & FG \\
\hline Content & $\begin{array}{l}\text { Respondents reported they like } \\
\text { to receive historical information } \\
\text { as well as useful information } \\
\text { such as transportation. }\end{array}$ & $\begin{array}{l}\text { The results indicate learners } \\
\text { like getting historical } \\
\text { information while they are } \\
\text { walking around, and finding out } \\
\text { extra information about sites }\end{array}$ & SS \\
\hline
\end{tabular}




\begin{tabular}{|c|c|c|c|}
\hline categories & Justification & Examples & $\mathrm{SC}$ \\
\hline & & $\begin{array}{l}\text { (e.g. public services or opening } \\
\text { times) as it gained } 53 \% \text { of } \\
\text { responses. }\end{array}$ & \\
\hline & $\begin{array}{l}\text { Participants mentioned } \\
\text { different types of information } \\
\text { that they would like to have } \\
\text { regarding cultural heritage sites } \\
\text { such as life back in time. }\end{array}$ & $\begin{array}{l}\text { "for learning from history, I } \\
\text { think just giving me just } \\
\text { sufficient information to } \\
\text { understand the historical } \\
\text { context of the social context of } \\
\text { where I am, not too much } \\
\text { information, I don't want it to } \\
\text { be like a lecture, but just } \\
\text { enough to understand this is } \\
\text { would've been like at this period } \\
\text { of time of history, this is why the } \\
\text { building is here, this is would've } \\
\text { happened in this building, this } \\
\text { is what happened as a result" } \\
\text { "I like to see pictures of the } \\
\text { place as it used to look in the } \\
\text { past" }\end{array}$ & IS \\
\hline & & $\begin{array}{l}\text { "...it can give you } \\
\text { information like taxis, buses, it } \\
\text { could be helpful or how farfrom } \\
\text { the bus station..." }\end{array}$ & FG \\
\hline $\begin{array}{l}\text { Learning } \\
\text { design }\end{array}$ & $\begin{array}{l}\text { Experiential, } \\
\text { collaborative, situated and } \\
\text { conversational learning }\end{array}$ & $\begin{array}{l}\text { "conversational systems } \\
\text { which allow mental activities to } \\
\text { be described in terms of } \\
\text { dialogue and behaviour" [48] }\end{array}$ & ToU \\
\hline
\end{tabular}




\begin{tabular}{|c|c|c|c|}
\hline categories & Justification & Examples & $\mathrm{SC}$ \\
\hline & $\begin{array}{l}\text { Respondents noted they visit } \\
\text { cultural heritage mainly for } \\
\text { learning. } \\
\text { The vast majority of } \\
\text { respondents claimed that using } \\
\text { mobile devices would assist them } \\
\text { accessing information whilst } \\
\text { they are moving and doing daily } \\
\text { activities. }\end{array}$ & $\begin{array}{l}\text { Learning is the main reason } \\
\text { that drives people to visit } \\
\text { cultural heritage site as } 86 \% \text { of } \\
\text { the questionnaire respondents } \\
\text { reported that. The other reason } \\
\text { is curiosity as } 70 \% \text { of } \\
\text { respondents stated that they like } \\
\text { to investigate the culture of } \\
\text { other countries. Another } \\
\text { mentioned reason is envisaging } \\
\text { the stories behind these sites } \\
\text { (58\%). All these reasons could } \\
\text { be categorised under the } \\
\text { learning category. }\end{array}$ & SS \\
\hline & $\begin{array}{l}\text { Participants stressed that } \\
\text { having instant historical } \\
\text { information while they are } \\
\text { moving would really save } \\
\text { their time and efforts. } \\
\text { Participants stated they } \\
\text { perform learning differently } \\
\text { and have different learning } \\
\text { preferences. }\end{array}$ & $\begin{array}{l}\text { “...going around place with } \\
\text { other people does mean there } \\
\text { will be a conversation, } \\
\text { conversation tends to improve } \\
\text { memory so it gets you thinking } \\
\text { more or probably remember } \\
\text { more about the site because I've } \\
\text { been talking with my friends } \\
\text { and I might not remember that } \\
\text { room very well but I will } \\
\text { remember the conversation we } \\
\text { had in that room about that } \\
\text { statue or that painting or those } \\
\text { artefacts...” }\end{array}$ & IS \\
\hline & & $\begin{array}{l}\text { "I would like to take my } \\
\text { children to historical site to } \\
\text { help them learn from them..." }\end{array}$ & FG \\
\hline
\end{tabular}




\begin{tabular}{|c|c|c|c|}
\hline categories & Justification & Examples & $\mathrm{SC}$ \\
\hline \multirow{3}{*}{$\begin{array}{l}\text { Interaction } \\
\text { design }\end{array}$} & $\begin{array}{l}\text { Respondents stated that they } \\
\text { would like to use different } \\
\text { services and multiple levels of } \\
\text { interaction at cultural heritage } \\
\text { sites. }\end{array}$ & $\begin{array}{l}76 \% \text { of respondents stated } \\
\text { that they would use mobile } \\
\text { devices at cultural heritage sites } \\
\text { and also } 89 \% \text { asserted that } \\
\text { mobile devices would facilitate } \\
\text { getting information regarding } \\
\text { the history of heritage places. } \\
\text { "Device needs to be flexible } \\
\text { as user may not want it on all } \\
\text { the time". }\end{array}$ & SS \\
\hline & \multirow[t]{2}{*}{$\begin{array}{l}\text { People interact with the } \\
\text { cultural heritage context in } \\
\text { different manners. They use } \\
\text { different resources and tools to } \\
\text { acquire information whether are } \\
\text { provided by the site or their own } \\
\text { devices. }\end{array}$} & $\begin{array}{l}\text { "...probably want an app } \\
\text { that connected to audio tours } \\
\text { not visual, something that I can } \\
\text { listen to [on] iPhone for } \\
\text { example could track where I am } \\
\text { then I would automatically } \\
\text { know where I was and be able } \\
\text { to give me the correct } \\
\text { information based on where I'm } \\
\text { standing” } \\
\text { “...I think the information } \\
\text { that you receive and platform } \\
\text { which presented to you } \\
\text { or directly affect } \\
\text { enjoyable the experience was } \\
\text { but also the amount of } \\
\text { information you take backfrom } \\
\text { it...” }\end{array}$ & IS \\
\hline & & $\begin{array}{c}\text { “.. [if the app is] more } \\
\text { complicated, more interaction }\end{array}$ & FG \\
\hline
\end{tabular}




\begin{tabular}{|c|c|c|c|}
\hline categories & Justification & Examples & $\mathrm{SC}$ \\
\hline & & $\begin{array}{l}\text { and more question you will lose } \\
\text { number of users..." }\end{array}$ & \\
\hline \multirow{3}{*}{ Contexts } & $\begin{array}{l}\text { People use mobile devices in } \\
\text { different places and contexts, } \\
\text { which include: at home, whilst } \\
\text { traveling, in the office, and on } \\
\text { holiday. }\end{array}$ & $\begin{array}{l}\text { Results show that people use } \\
\text { mobile devices at different } \\
\text { places and contexts which } \\
\text { include: at home }(96 \%) \text {, whilst } \\
\text { traveling ( } 89 \%) \text {, in the office } \\
(67 \%) \text {, and on holiday ( } 78 \%) \text {. } \\
33 \% \text { of respondents reported } \\
\text { that they visit cultural heritage } \\
\text { sites when they are on holiday. }\end{array}$ & SS \\
\hline & \multirow[t]{2}{*}{$\begin{array}{l}\text { People visit sites individually } \\
\text { and in groups; being with a group } \\
\text { might bring different experiences } \\
\text { than on their own; being with } \\
\text { others helps remember } \\
\text { information which enhances the } \\
\text { learning experience. }\end{array}$} & $\begin{array}{l}\text { "...I can remember that feel } \\
\text { it is very personal, personal } \\
\text { experience, when you with } \\
\text { somebody else may be you talk } \\
\text { about, oh its Jasmin that's } \\
\text { interesting it feels beautiful, but } \\
\text { may be you don't hold this } \\
\text { sensation [of the place]" }\end{array}$ & IS \\
\hline & & $\begin{array}{l}\text { "...I might go to visit cultural } \\
\text { heritage or historical sites if I } \\
\text { am on holiday in another } \\
\text { country" }\end{array}$ & FG \\
\hline $\begin{array}{r}\text { Challenges } \\
\text { and obstacles }\end{array}$ & $\begin{array}{l}\text { The results highlight some } \\
\text { challenges regarding using } \\
\text { technology to learn at cultural } \\
\text { heritage sites. }\end{array}$ & $\begin{array}{l}\text { Some respondents said that } \\
\text { they do not use mobile devices } \\
\text { at cultural heritage sites ( } 23 \%) \text {. } \\
\text { "Don't take mobile on } \\
\text { holiday and only visit sites on } \\
\text { holiday" }\end{array}$ & SS \\
\hline
\end{tabular}




\begin{tabular}{|c|c|c|c|}
\hline categories & Justification & Examples & $\mathrm{SC}$ \\
\hline & $\begin{array}{l}\text { A number of challenges were } \\
\text { highlighted by the field studies: } \\
\text { confidentiality, financial issue } \\
\text { and people's preferences. }\end{array}$ & $\begin{array}{l}\text { “...I think it [technology] } \\
\text { takes [away] some of the dream } \\
\text { and the fantasy...”, “...I don't } \\
\text { think and I don't think I would } \\
\text { [use technology at sites], I } \\
\text { know personally I would get } \\
\text { frustrated with technology } \\
\text { instead of enjoying being in } \\
\text { historical place, that for me is } \\
\text { the extreme opposite of the } \\
\text { experience that I want to have, } \\
\text { I want to get lost in the history } \\
\text { and in the time before } \\
\text { technology" }\end{array}$ & IS \\
\hline & & $\begin{array}{l}\text { “... [people] may not feel } \\
\text { comfortable with something } \\
\text { knows where they are..." }\end{array}$ & FG \\
\hline
\end{tabular}

FoSLE provides information to support the design of such services, each category provides different types of information that serves this particular aspect (see Section 8 for more details); the details of each category are given in the next sub-sections.

\subsection{Learner}

The learner is the core element in the informal learning process as they in charge of their learning experience. People differ in their characteristics and habits in all life's aspects including learning [86]. Consequently, they do not perform learning in the same manner, they perceive learning differently, take learning opportunities in different ways and have different learning preferences [10]. In cultural heritage contexts people visit sites individually and in groups (family or friends), as well as in different age groups. Each group has different needs and preferences [87], and it is clear from the current data that people prefer to customise their apps based on their preferences (see Table 2), but more than that, they really prefer the app to customise itself intelligently by tracking their route and history of previous interactions. 


\subsection{Content}

The content is an important element in the learning process whether it is a learning material or useful information as both types would assist learners in performing learning more efficiently. Learning content is the material that learners consume to construe history as well as make sense of historical places. Designing a content object could make delivering information more efficiently that could help in making sense of the attractions in a one or different area(s) as one object. The value of the content object is that it connects all the related sites and attractions whether they have experienced the same events over times, or experienced different events in one particular period of time. In order to envisage the full picture of events that have had happened at that site, different types of historical information need to be involved, which in turn helps people to have a full experience of sites. Furthermore, to help learners engage with the content, reliable and interesting historical information should be provided, also the level of detail should be adapted based on a learner's understanding [17]. In addition, information regarding public services such as cafes and transport would be very useful for visitors (see Table 2). On this basis, content could be categorised into two types, (a) learning material (e.g. life back in time, human achievements, interesting facts and funny stories), and (b) useful information (e.g. the weather, transportation, tickets, opening times, and public facilities such playground for children, and a place to eat).

\subsection{Learning Design}

Learning happens spontaneously while people carry out their daily activities and experiencing life, and they might not even be aware that they are learning. Tough [88] points out that people mainly undertake a learning project to gain new knowledge or skills that could improve people's life, such as change one's habits or completing tasks related to one's job, home or family.

Learning is the main reason that drives people to visit cultural heritage sites for themselves or for their children even if they do not perceive the trip as learning, either locally or abroad to discover other communities' cultures. It also was reported that visiting cultural heritage sites helps in raising awareness of culture and attaching people to their communities as well as preserving these sites. Moreover, envisaging the stories behind the cultural heritage sites may support people to maintain the link between the past and the present, which in turn sustains the culture. In addition, cultural heritage sites are also seen as a form of worthy entertainment, as most people visit cultural heritage sites at least once a year, which could contribute significantly to the countries' income. Moreover, visiting heritage places and experiencing the past by 
exploring their history would enhance learner's perception [89]. Therefore, it is significant to utilise means that make learning experiences at sites more efficient and pleasurable.

As taking a new learning experience could be a challenge especially if it is a self-directed process, it is important to assist learners in designing their learning journey [90]. The learning design might include: (a) motivation that drives learners to visit cultural heritage sites (e.g. watching a historical film about that period of time), (b) learning types, and (c) learning preferences. Learners perform different types of learning in different contexts such as individually, collaboratively, socially as well as learning on-the-move as the current data highlight. Learners tend to have different preferences to perform learning based on the contexts of learning $[10,91]$. There are some learners who are visualising and enjoy seeing artefacts, which might let their imagination to take over. Others like challenging and adventures such as quizzes and geo-caching (Mortara, Catalano, Bellotti, Fiucci, Houry-Panchetti \& Petridis, 2014), which might help them to remember information to which they were exposed to during the activity. Additionally, some learners like to engage with a story that tells a historical event in an interesting way. Learning by doing is a preference for some learners in which they engage in an activity that might demonstrate life back in time. In short, providing different activities that meet learners' needs in different stages during their visit to cultural heritage sites could help them in taking a learning experience more easily. Moreover, enabling different types of learning could make the learning process more enjoyable (see Table 2).

\subsection{Interaction Design}

Interaction design is considered a key aspect in drawing the user's attention to new technologies [92]. People use different types of mobile devices in different contexts and spaces for almost all daily activities including learning at cultural heritage sites. As users deal with services via interfaces, it becomes essential to carefully design such services.

Presenting information in an interesting way would help enhance visitors/learners' engagement such as providing multiple modalities for delivering historical information. Another way of presenting information is delivering information through multiple screens and allowing learners to choose between them to suit the current context of use. This would support learners to engage their sight with the artefacts when observing them, while simultaneously receiving information through wearable devices, such as smart eye glasses. Wearable devices, such as smart eye glasses, could be instructed using visitors' voice [3], which would free visitors' hands completely. In this sense, wearable devices would enable learners to interact 
with contexts conveniently and effectively, which would significantly enhance the interaction. That, in turn, would enhance learning from cultural heritage sites.

One interesting issue that was raised in the field studies is the fact that people are motivated to see how cultural heritage sites used to be in the past. Presenting information based on users' profile and learning preferences could convince people to visit sites [93]. That could enhance learning from cultural heritage sites. Another aspects would make the use easier are: providing options to abort or switch off services when they are not needed at any stage of learning, and switching smoothly between different devices. Since adaptation is a significant aspect within the interaction design, it is important to introduce a service that could be adapted according to the surrounding environment and user profile in terms of contents, devices, functionality and interfaces (see Table 2). In short, interaction design could include: (a) usability aspects, (b) adaptation, and (c) interaction with the context (i.e. services and activities, and delivering historical information).

\subsection{Context}

Learning could take place at any time and in any context as there is no restriction of time and place for learning. People use mobile devices for learning whenever they need regardless of time and place which supports the concept that learning is mobile [94]. People experience sites differently such as, individually or in groups, and within groups people come with friends, family or as a guided-group (see Table 2). Some people visit sites only on holiday to discover other cultures, whereas others like to visit sites regularly such as once a month and they enjoy visiting the same site more than one time. Moreover, some people are not able to be at sites physically for some reason such as they are in a far geographic area, which could benefit from distance learning (distance visit) through ubiquitous devices. distance learning would provide a great opportunity for learners who are not able be physically at sites for any reason [95]. All these aspects use different contexts for learning. Hence, considering different contexts could have a significant impact on learning outcomes, which can be addressed with an adaptation mechanisms to effectively respond to different contexts of use [96]. In a summary, this research identified a few learning contexts in terms of: (a) time of the visit (e.g. busy or quiet), (b) place (e.g. a new place), (c) type of visit (e.g. individual or a group) and (d) learners' physical state (e.g. moving or in a settled situation (i.e. sitting)).

\subsection{Challenges and Obstacles}


Although learning in outdoors settings has its own benefits [97], it might raise some challenges with using mobile services, such as weather issues as both rain and sun spells might affect the experience. The network's quality, the cost and the confidentiality could be significant issues. Visitor's level of knowledge in using technology might obstruct the experience. These issues should be taken into account when designing such services and providing some alternatives such as displaying clear errors and process messages and applying an adaptation mechanism. Moreover, some people do not use internet on their mobile phone for financial issue, which might prevent them from using such services. Additionally, visitors' preferences need to be accommodated, as some people are not very keen to use technology at cultural heritage sites, because from their point of view it takes the imagination away and because they would like to use all their senses there (see Table 2). However, technology is growing so rapidly, which introduces different services that might draw people's interest and enable them to choose how to experience the sites. Some new technologies have been released recently that help people experience life back in time by enabling them to use all their senses, i.e. smell, touch and hearing [98]. In a summary, challenges could be categorised as: (a) confidentiality issues, (b) financial issues, (c) tools and devices related issues, (d) surroundings related issues and, learners related issues.

The framework was used to design a proof-of-concept mobile application prototype, SmartC, as described in the next section.

\section{The design of a Proof-of-concept - A Mobile Application Prototype}

The framework was further analysed to pull out a set of general requirements (GRs) for designing such services. The identified general requirements guided the design of a proof-ofconcept, which highlighted what could be developed based on the framework. The set of general requirements with the related framework category (FC) are given below.

\section{Learner:}

GR1: The service should maintain a learner model.

\section{Content:}

GR2: The service should maintain a content object.

Learning design:

GR3: The service should support different types of learning and learning preferences.

GR4: The service should support learning design that assists learners in organising their visit. 
GR5: The service should support learning on-the-move.

GR6: The service should support learners to communicate with each other. Interaction design:

GR7: The service should support an interaction design that suit learners. Context:

GR8:The service should consider the context where, when and how people use a mobile app;

Challenges and obstacles:

GR9: The service should provide alternatives that suit learners to solve problems and challenges.

Based on a subset of these requirements, a prototype mobile app of a context-aware service was designed for outdoor cultural heritage settings, SmartC. This native android app uses location-based services (LBS) to identify visitors' location to allow the device to provide instant information on-the-move about nearby cultural heritage sites, in line with the purpose of smart environments: "a smart learning system can be perceived as a technology-enhanced learning system that is capable of advising learners to learn in the real-world with access to the digital world resources" Hwang [3].

Geo-fence technology was used, which is placing a virtual boundary around a geographical area. It works when a user enters or leaves the area, which is identified by latitude and longitude of the area [99]. The mobile device gets triggered when a learner enters that virtual zone, which it is tracked using the global position system (GPS) of the device. The device pushes a notification to alert the learner when he/she gets close to an attraction. Notifications are pushed via the app through the mobile-based interface and the glasses-based interface simultaneously when the mobile device gets triggered (see Figure 4). As an interesting aspect was raised in the field studies, which is seeing attractions how they appeared in the past, augmented reality (AR) technology was utilised to play this role. Additionally, wearable computing devices (smart eye glasses) was utilised to carry out a further investigation in context. SmartC uses Sony smart eye glasses to deliver notifications based on learners' location simultaneously with the mobile. 


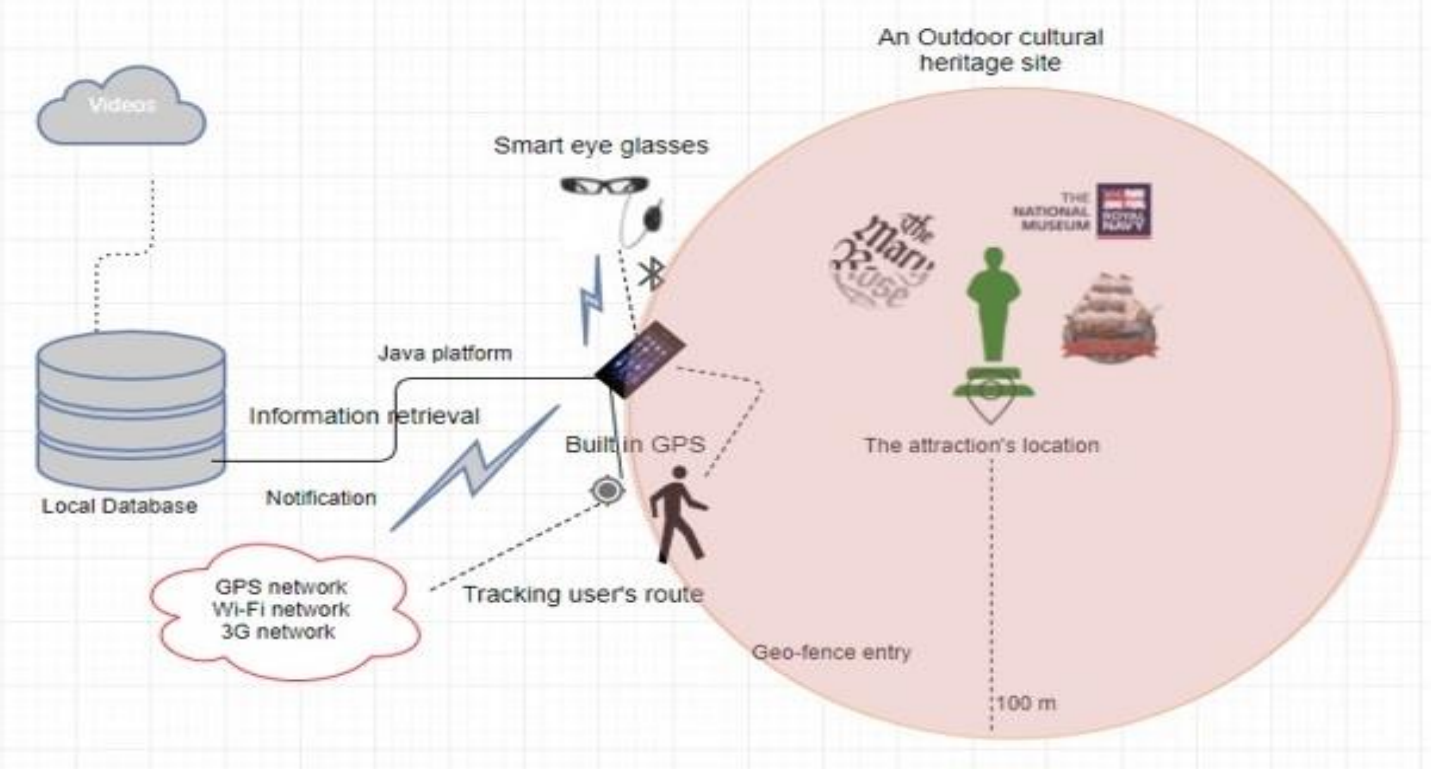

Figure 4. The SmartC architecture [1]

The main features of the app, which responded to a subset of the general requirements, are given in the Table 3.

Table 3. Linking the features to the requirements and the justification for choosing them

\begin{tabular}{|l|l|l|}
\hline GRs & \multicolumn{1}{|c|}{ Features } & Justification \\
\hline $1 \quad \&$ & $\begin{array}{l}\text { Receiving notification based on the current } \\
\text { location through the mobile device and the } \\
\text { glasses }\end{array}$ & $\begin{array}{l}\text { learning on-the-move; carry out } \\
\text { further investigation }\end{array}$ \\
\hline $\begin{array}{l}1,2, \\
3,\end{array}$ & $\begin{array}{l}\text { Having a multimode information format to } \\
\text { present historical information (i.e. text, } \\
7\end{array}$ & $\begin{array}{l}\text { images, audio, \& video) } \\
\text { participants }\end{array}$ \\
\hline 2,3 & $\begin{array}{l}\text { Providing a service to show how sites } \\
\text { looked in the past. }\end{array}$ & $\begin{array}{l}\text { carry out further investigation in } \\
\text { the context }\end{array}$ \\
\hline 9 & Error and process messages & $\begin{array}{l}\text { Help users understand what is } \\
\text { happening }\end{array}$ \\
\hline
\end{tabular}

The visitor starts the service by switching the notification $O N$ and walks close to attractions (see Figure 5-a). An alert and a notification come up when passing nearby an attraction; an opportunity to see more details will be given if the visitor would like to (see Figure 5-b). A multimode information format is provided in the attraction's page to present historical information (i.e. text, image, audio and video). In addition, a camera could be used to take a photo without leaving the app. Both services Video and Camera appear when pressing on the 
More button (see Figure 5-c). Moreover, the app gives visitors an opportunity to see attractions as they looked in the past by providing the See-it-in-the-past feature. The See-it-in-the-past

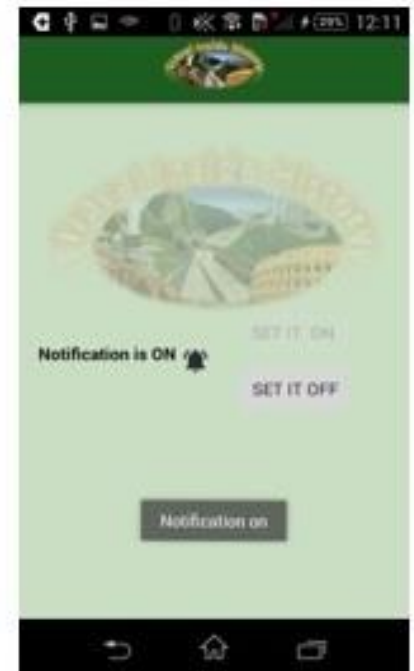

Figure a. Initial page

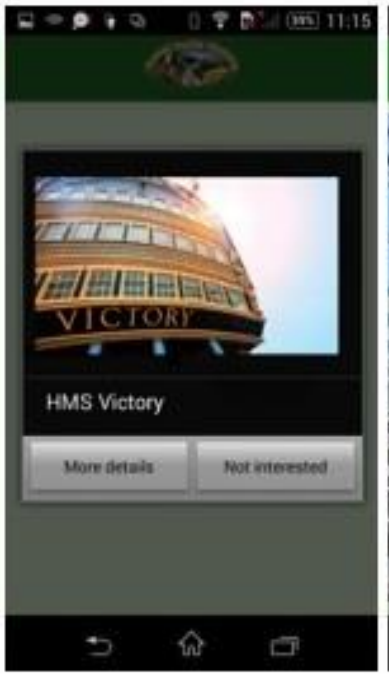

Figure b. Viewed notification

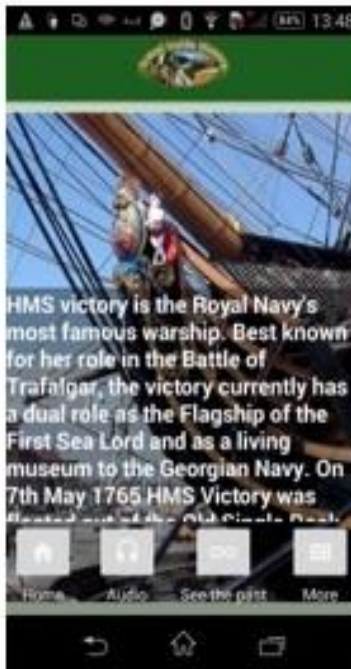

Figure c. Attraction page

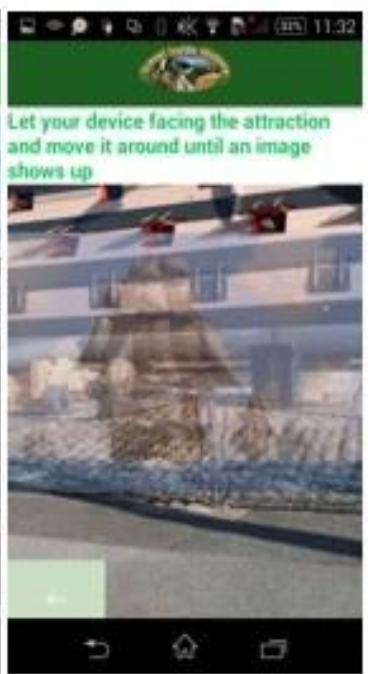

Figure d. "See-in-thepast" page

Figure 5. SmartC main screens - mobile based [1]

The notification could also be viewed through the mobile device or the glasses. The smart eye glasses used with this app would enhance visitors' engagements at sites and consequently enhance the experience, as well as frees their hands while walking around at the site (see Figure 6). However, in this version of the app, the visitor needs to use the mobile phone to access the historical information.

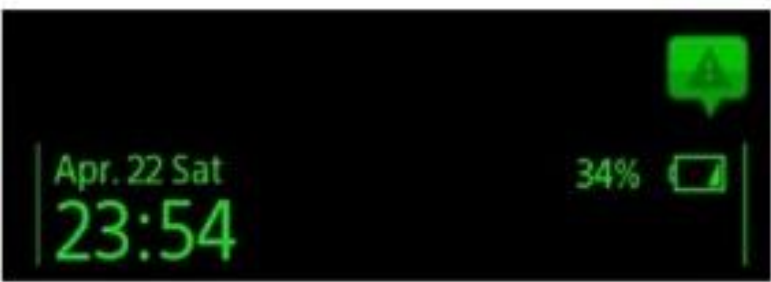

HMS Victory

A warship where lord Nelson died

Figure 6. SmartEyeGglasses-based notification's interface [1]

As presented, SmartC provides features considered interesting based on the field studies, which some of them were introduced in other studies as mentioned earlier in section 1 and 3 such as using AR and LBS for cultural heritage sites. However, none of the mentioned studies support learning on-the-move, where visitors receive information automatically while moving based on location regarding the sorrounding cultural heritage sites without any interfering from 
them. In addition, SmartC provides a service to show attractions how looked in the past through a mobile phone and smart eye glasses, which none of the mentioned studies provides for outdoor settings and in combination with the learning on-the-move service. Utilising smart and wearable computing would be a great turn in interaction with the context of cultural heritage, which would enhance sites interpretation as well as visitors experience. The next section discusses the framework and outlines its contribution.

\section{Discussion}

Learning is always inspiring researchers to explore it further and introduce models and frameworks to assist practitioners and other researchers in the field of learning. A number of models and frameworks have been introduced to support informal learning in different contexts. Section 3 discussed learning models and framework in detail, which are summarised in this section to highlight their similarities and differences with the FoSLE framework.

The discussion in the section 3 revealed that some presented models and frameworks showed some similarities with the proposed framework, FoSLE, in terms of the context they were proposed for, which is outdoors cultural heritage, such as [100], supporting learning onthe-move at outdoor settings, such as [3], for interaction design [71, 100] as well as some others for supporting different aspects in informal/ lifelong learning contexts, such as [57, 61$63,65,67,101]$; however, none of them was introduced for supporting the particular need of learning on-the-move at outdoors cultural heritage, where variables such as noise and weather are not easy to control. Additionally, only few of them considered learners' perspectives when formulating the models/frameworks, which could be an essential requirement for delivering an adaptive learning mechanism. Adaptive learning is an important aspect in such context as it would enhance engagement due to that learners/visitors are able to receive services based on their profile, context and location, which means the services could be adapted based on these aspects. Given that, each model/framework would not be sufficient alone for designing such services, which would need to be integrated with one or more models in order to provide a learning environment that has the essential elements for such services in such context.

While our framework shares some aspects with the previous studies related to informal learning, including learner model, learning design and enhancing the learning process, it also identified a number of aspects that are essential for supporting informal learning at outdoor cultural heritage sites, which are not included in previous studies (See table 4), such as: (a) learning on-the-move, (b) the importance of content and its format (tying in with the entertainment aspect) and (c) interaction with context and specific challenges. In addition, 
unlike previous works, the use of wearable computing to support informal learning was investigated.

Supporting learning on-the-move would be considered as an important type of learning in the current time, which helps learners keep up with the rapid pace of life. Learning in cultural heritage context has different needs in terms of content, activities and interaction to make it efficient and pleasurable, as learners see it as a form of entertainment and not necessarily learning. in terms of content, it is important to provide interesting information that is presented in an engagement way to contribute to enhance engagement, which would make the journey more interesting as we mentioned earlier, visitors perceive it as a pleasure trip. The FoSLE framework considers this aspect by providing content model, which provides different types of information participants showed a great interest to, such as: how people back in time used to live, and how they managed to get through difficult time for instance. Additionally, the interaction between visitors and the context would bring a great pleasure to the journey if engaging services are provided based on the field studies. FoSLE suggests several levels of interaction, which would accommodate different charecterstics and needs; moreover, it suggests interactions' materials that would be considered great tools to enhance engagement such as adopting smart eye glasses and immersive technologies. Smart eye glasses would enhance the interaction in terms of freeing visitors hands as well as give them an opportunity to receive information regarding attractions while at the same time associate their shight with the phisycal artefacts.

FoSLE was designed to enhance visitors' experience by considering all the aforementioned aspects alongside user profiles, which would also enhance visitors/learners' engagement by providing adaptive learning. Additionally, it utilises mobile and wearable technologies that are seen as important elements in supporting ubiquitous learning, which support people learn while moving regardless of time and place. Table 4 illustrates the differences in features between the proposed one, FoSLE, and similar models/frameworks. 
Table 4. Comparison between FoSLE and other models/frameworks for informal learning

\begin{tabular}{|c|c|c|c|c|c|c|c|c|c|c|c|c|c|c|c|}
\hline \multirow[b]{2}{*}{ 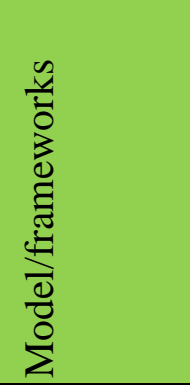 } & \multirow[b]{2}{*}{ 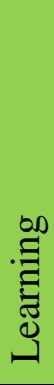 } & \multirow[b]{2}{*}{ 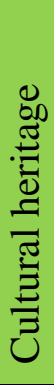 } & \multirow[b]{2}{*}{ 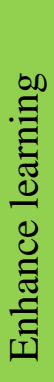 } & \multirow[b]{2}{*}{ 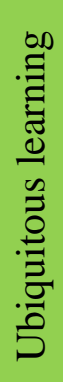 } & \multicolumn{11}{|c|}{ Features } \\
\hline & & & & & 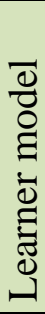 & 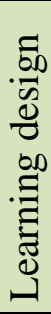 & 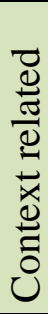 & 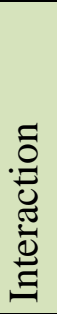 & 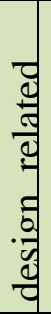 & $\begin{array}{l}\frac{\tilde{U}}{0} \\
.0 \\
0 \\
\stackrel{0}{0} \\
\stackrel{0}{0}\end{array}$ & 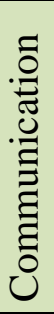 & 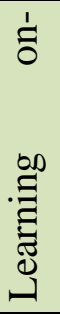 & 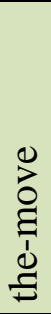 & 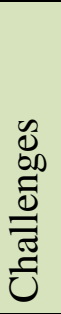 & 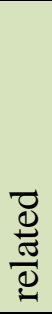 \\
\hline FoSLE & $\mathrm{X}$ & $\mathrm{X}$ & $\mathrm{X}$ & $\mathrm{X}$ & $\mathrm{X}$ & $\mathrm{X}$ & $\mathrm{X}$ & $\mathrm{X}$ & & $\mathrm{X}$ & $\mathrm{X}$ & $\mathrm{X}$ & & $x$ & \\
\hline FoLL & $\mathrm{x}$ & & & & $\mathrm{x}$ & $\mathrm{x}$ & $\mathrm{x}$ & & & & & & & $x$ & \\
\hline Li's & $\mathrm{X}$ & & & $\mathrm{X}$ & & & & & & & $\mathrm{X}$ & & & & \\
\hline Zhang's & $X$ & & & & & & & & & & $\mathrm{X}$ & & & & \\
\hline Taylor & $X$ & & X & X & & & X & & & & X & & & & \\
\hline Nino's & $\mathrm{X}$ & & & & & & & & & & $\mathrm{X}$ & & & & \\
\hline Saccol's & X & & X & X & X & X & X & & & & $\mathrm{X}$ & & & $X$ & \\
\hline LOCAL & $\mathrm{X}$ & & $\mathrm{X}$ & $\mathrm{X}$ & $\mathrm{X}$ & $\mathrm{X}$ & $\mathrm{X}$ & & & & $\mathrm{X}$ & & & $X$ & \\
\hline Candello's & X & $\mathrm{X}$ & & X & & & & X & & $\mathrm{x}$ & & & & $X$ & \\
\hline Saeed's & & & & & & & & $\mathrm{X}$ & & & & & & & \\
\hline Hwang's & $\mathrm{X}$ & & X & X & X & X & & & & & & $\mathrm{X}$ & & & \\
\hline
\end{tabular}

Based on the discussion so far, it is clear that there is a lack of models/frameworks that could support essential elements in designing informal learning services for outdoor cultural heritage sites. These aspects include: interaction design, designing a content object and also support different types of learning. In addition, none of the aforementioned models support learning on-the-move, where learners receive instant information regarding the surrounding sites based on location.

\section{Conclusions, Limitations and Further Work}

A theoretical framework, FoSLE, was introduced in this paper, which was resulted from three field studies and the investigation of theories of use. The framework consists of six broad categories: learner, content, learning design, interaction design, context and, obstacles and challenges. A set of general requirements was derived from the framework and translated into features and services to design a prototype mobile application with the following core features: 
(a) receiving notifications based on current location; (b) providing multiple ways of presenting historical information; (c) providing a service to show how attractions looked in the past using AR.

FoSLE was designed to fill the gap in the literature in terms providing a sufficient tool to assist researchers and designers in such field, which included aspects needed in designing tools for enhancing learning experience in outdoor cultural heritage sites, which the review of literature showed a lack of such tools.

To use this framework efficiently, researchers and designers are free to choose the part that better serves their design, or to use an element or more from each category to fulfil their design as there is no restriction for that. The main concept of it, is to make the design serves the learner in the best way to obtain a better learning experience at sites with the minimum challenges as possible. The framework provides information for developing such services to be implemented in a smart and ubiquitous learning environment (S-ULE) system, which the learner/visitor will use to interact with the real-world (i.e. outdoors cultural heritage contexts). The use of the framework is supposed to be through a set of general requirements, which then should be translated into features and service in a working system that will be used in an outdoor cultural heritage site. Figure 7 illustrates the process of translating the framework into S-ULE. The types of information that each category would provide are given below:

- Learner: this category provides information regarding visitors' characteristics and preferences based on users' profile.

- Content: this category provides information regarding user the types of information that serve this context in an interesting and engaging way.

- Learning design: this category provides information regarding user types of experience, learning and learning preferences that would help drawing learners/visitors' interest to take this learning opportunity in such context. Also, this category provides information regarding how services could motivate visitors to visit sites.

- Interaction design: this category provides information regarding types of services that would serve this type of contexts in an interesting and engaging way. Also, this category provides information regarding information format that could serve this service, which would enhance engagements. Additionally, it provides information regarding how the experience could be more interesting in such a context.

- Context: This category provides information regarding the different types of context and how could this support the experience in a positive way. 
- Challenges and obstacles: This category provides information regarding the challenges that might be encountered in such context with the aim of preventing them.

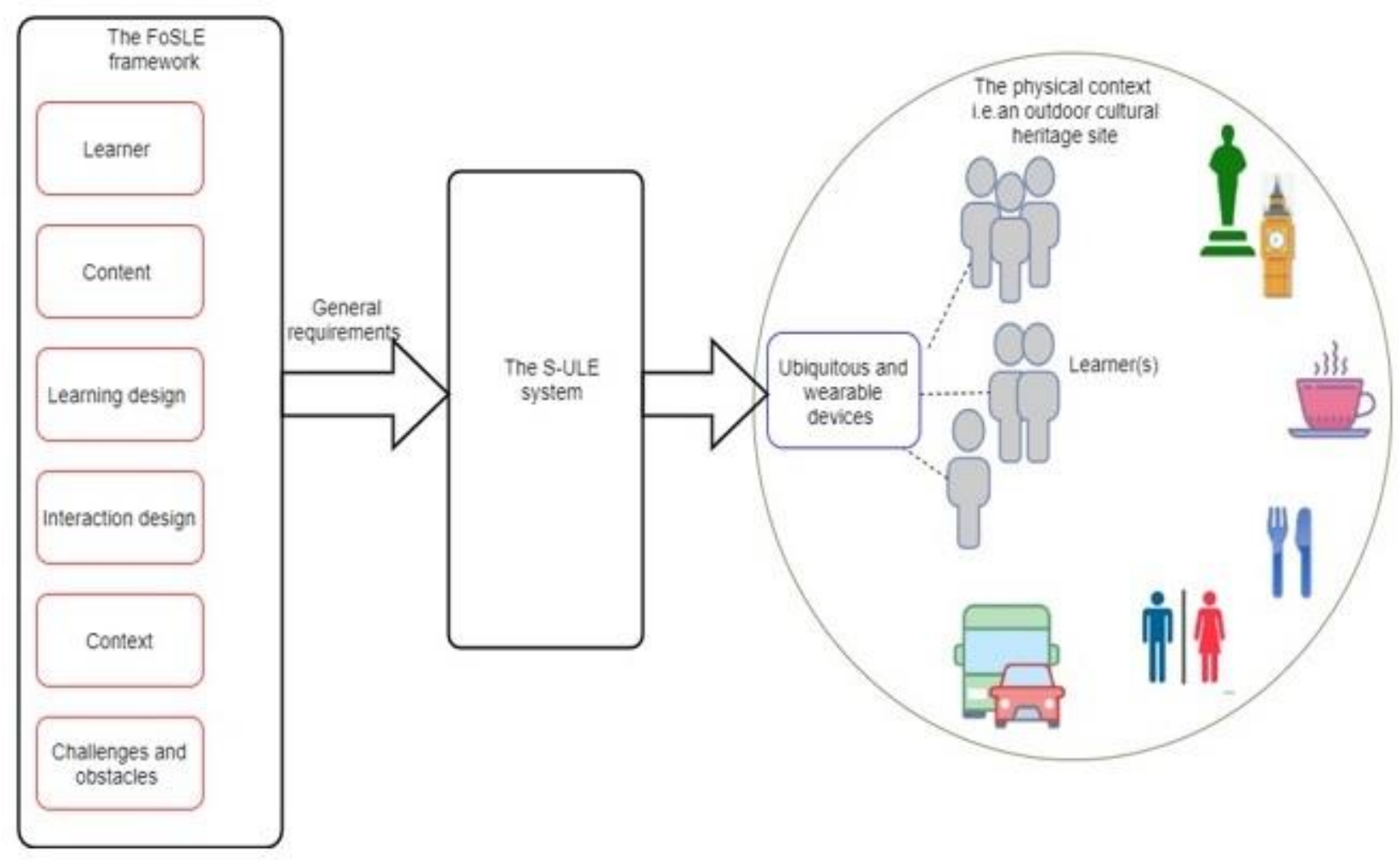

Figure 7: A graphical illustration of the proccess of translating FoSLE to a working system

However, FoSLE encountres some limitation, which include:

1) The convenience sampling method might not allow generalising the framework due to the nature of the sample, as it may not be representative of the entire user population.

2) Although participants were from different nationalities and background, most of them were residents in the UK, which may have introduced a cultural bias.

3) The categories might not cover absolutely every aspect in the design as some were notwidley included in the research such as technical aspects of the design, which only mentioned as challenges.

4) The proof-of-concept responded to a sub-set of the general requiremnts, which more GRs need to be included.

5) The "See it in the past" feature that uses AR, is limited to use a static 2D image to show how attarcations looked in the past. 
6) The use of wearable computing was limited to smart eye glasses, more wearable devices could be included

7) The use of smart eye glasses is limited to show the notification

Therefore, to address these limitations:

1- An extension to this work would be the replication of the study with more participants using different sampling methods and broadening the research context to more countries. Addionally, include more aspects in the research such as the technical side of the design.

2-Enhance the proof-of-concept, SmartC to include more GRs in the design the proof-ofconcept.

3-Enhance the "see in the past" feature to include a 3D construction of the attraction to show how these looked in the past from different angles.

4-Extend the features of SmartC to be included in the Smart Eye glasses and include more wearable devices.

These would be good directions to be investigated further.

We envision to carry out further research includes the evaluation of the prototype in the field with experts of cultural heritage, human computer interaction (HCI) and end-users, which will help enhance the current version of the framework. Ethnography research will be used in the field using a combination of observation and interview techniques alongside the cognitive walkthrough method for the experts' study and ISO metric questionnaire for the user study. 


\section{References}

[1] A. S. A. Alkhafaji, S. Fallahkhair, and M. Cocea, "Developing recommendations for designing smart and ubiquitous learning environments to be used at outdoors cultural heritage," Interaction Design and Architecture (s), no. 39, pp. 7-43, 2019.

[2] G. J. Hwang and C. C. Tsai, "Research trends in mobile and ubiquitous learning: A review of publications in selected journals from 2001 to 2010," British Journal of Educational Technology, vol. 42, no. 4, pp. E65-E70, 2011.

[3] G.-J. Hwang, "Definition, framework and research issues of smart learning environments-a contextaware ubiquitous learning perspective," Smart Learning Environments, vol. 1, no. 1, p. 4, 2014.

[4] A. Chianese, F. Piccialli, and I. Valente, "Smart environments and cultural heritage: a novel approach to create intelligent cultural spaces," Journal of Location Based Services, vol. 9, no. 3, pp. 209-234, 2015.

[5] A. Alkhafaji, S. Fallahkhair, and M. Cocea, "Towards gathering initial requirements of developing a mobile service to support informal learning at cultural heritage sites," Cognition And Exploratory Learning In The Digital Age (CELDA 2015), p. 51, 2015.

[6] H. L. Ainsworth and S. E. Eaton, Formal, Non-Formal and Informal Learning in the Sciences. ERIC, 2010.

[7] F. D. Davis, "Perceived usefulness, perceived ease of use, and user acceptance of information technology," MIS quarterly, pp. 319-340, 1989.

[8] M. Albanese, A. d'Acierno, V. Moscato, F. Persia, and A. Picariello, "A multimedia semantic recommender system for cultural heritage applications," in Semantic Computing (ICSC), 2011 Fifth IEEE International Conference on, 2011: IEEE, pp. 403-410.

[9] J. M. Reid, "The learning style preferences of ESL students," TESOL quarterly, vol. 21, no. 1, pp. 87111, 1987.

[10] E. Sadler-Smith, C. W. Allinson, and J. Hayes, "Learning preferences and cognitive style some implications for continuing professional development," Management Learning, vol. 31, no. 2, pp. 239256, 2000.

[11] N. Bevan, "ISO 9241: Ergonomic requirements for office work with visual display terminals (VDTs)Part 11: Guidance on usability," TC, vol. 159, 1998.

[12] S. Boiano, J. P. Bowen, and G. Gaia, "Usability, Design and Content Issues of Mobile Apps for Cultural Heritage Promotion: The Malta Culture Guide Experience," arXiv preprint arXiv:1207.3422, 2012.

[13] A. Alharthi, M. Spichkova, and M. Hamilton, "Sustainability requirements for eLearning systems: a systematic literature review and analysis," Requirements Engineering, vol. 24, pp. 523-543, 2019.

[14] R. Kasauli, G. Liebel, E. Knauss, S. Gopakumar, and B. Kanagwa, "Requirements Engineering Challenges in Large-Scale Agile System Development," presented at the Requirements Engineering Conf. (RE '17), Lisbon, Portugal, 2017.

[15] V. J. Marsick and K. E. Watkins, "Informal and incidental learning," New directions for adult and continuing education, vol. 2001, no. 89, pp. 25-34, 2001.

[16] R. Koper et al., "A design model for lifelong learning networks," Interactive Learning Environments, vol. 13, no. 1-2, pp. 71-92, 2005.

[17] E. FitzGerald, "Creating user-generated content for location-based learning: an authoring framework," Journal of Computer Assisted Learning, vol. 28, no. 3, pp. 195-207, 2012.

[18] J.-L. Shih, C.-W. Chuang, and G.-J. Hwang, "An inquiry-based mobile learning approach to enhancing social science learning effectiveness," Journal of Educational Technology \& Society, vol. 13, no. 4, pp. 50-62, 2010.

[19] G. J. Hwang and S. C. Chang, "Effects of a peer competition-based mobile learning approach on students' affective domain exhibition in social studies courses," British Journal of Educational Technology, vol. 47, no. 6, pp. 1217-1231, 2016.

[20] E. Litvak and T. Kuflik, "Enhancing cultural heritage outdoor experience with augmented-reality smart glasses," Personal and Ubiquitous Computing, pp. 1-14, 2020.

[21] M. K. Bekele, "Walkable Mixed Reality Map as interaction interface for Virtual Heritage," Digital Applications in Archaeology and Cultural Heritage, vol. 15, p. e00127, 2019.

[22] M. Khalaf, "Smart cultural heritage: Technologies and applications," 2019.

[23] G. Vavoula and M. Mason, "Digital exhibition design: boundary crossing, Intermediary Design Deliverables and processes of consent," Museum Management and Curatorship, vol. 32, no. 3, pp. 251271, 2017.

[24] W. S. N. Ayudhya and G. Vavoula, "Mobile family learning in the science museum," in Proceedings of the 16th World Conference on Mobile and Contextual Learning, 2017, pp. 1-8. 
[25] I. Koren and R. Klamma, "Smart Ambient Learning with Physical Artifacts Using Wearable Technologies," in Intelligent Environments (Workshops), 2015, pp. 325-332.

[26] S. Blanco-Pons, B. Carrion-Ruiz, J. L. Lerma, and V. Villaverde, "Design and implementation of an augmented reality application for rock art visualization in Cova dels Cavalls (Spain)," Journal of Cultural Heritage, vol. 39, pp. 177-185, 2019.

[27] F. Cesaria, A. M. Cucinelli, G. De Prezzo, and I. Spada, "Gamification in Cultural Heritage: A Tangible User Interface Game for Learning About Local Heritage," in Digital Cultural Heritage: Springer, 2020, pp. 411-422.

[28] E. Nofal, G. Panagiotidou, R. M. Reffat, H. Hameeuw, V. Boschloos, and A. V. Moere, "Situated Tangible Gamification of Heritage for Supporting Collaborative Learning of Young Museum Visitors," Journal on Computing and Cultural Heritage (JOCCH), vol. 13, no. 1, pp. 1-24, 2020.

[29] C. H. Su and C. H. Cheng, "A mobile gamification learning system for improving the learning motivation and achievements," Journal of Computer Assisted Learning, vol. 31, no. 3, pp. 268-286, 2015.

[30] G. Varinlioglu and S. M. Halici, "Gamification of Heritage through Augmented Reality," 2019.

[31] Y. Weng, T. Shen, S. Chen, and B. Xiao, "Gamification in Local Intangible Cultural Heritage Museums for Children: A Case Design," in International Conference on Human-Computer Interaction, 2019: Springer, pp. 233-245.

[32] K. Tan and C. Lim, "Digital Heritage Gamification: An Augmented-Virtual Walkthrough to Learn and Explore Tangible Cultural Heritage," Journal of Telecommunication, Electronic and Computer Engineering (JTEC), vol. 9, no. 2-12, pp. 125-129, 2017.

[33] J. Lee, J. Kim, J. Ahn, and W. Woo, "Context-aware risk management for architectural heritage using historic building information modeling and virtual reality," Journal of Cultural Heritage, vol. 38, pp. 242-252, 2019.

[34] H. Kolivand, A. El Rhalibi, M. S. Sunar, and T. Saba, "ReVitAge: Realistic virtual heritage taking shadows and sky illumination into account," Journal of Cultural Heritage, vol. 32, pp. 166-175, 2018.

[35] P. Dourish, "What we talk about when we talk about context," Personal and Ubiquitous Computing, vol. 8, no. 1, pp. 19-30, 2004.

[36] M. Weiser, "Ubiquitous computing," Computer, vol. 26, no. 10, pp. 71-72, 1993.

[37] P.-L. P. Rau, Q. Gao, and L.-M. Wu, "Using mobile communication technology in high school education: Motivation, pressure, and learning performance," Computers \& Education, vol. 50, no. 1, pp. 1-22, 2008.

[38] N. Pachler, B. Bachmair, J. Cook, and G. Kress, Mobile learning. Springer, 2010.

[39] M. Sharples, "The Design of Personal Mobile Technologies for Lifelong Learning," Computers \& Education, vol. 34, no. 3, pp. 177-193 2000.

[40] M. Eraut, "Informal learning in the workplace," Studies in Continuing Education, vol. 26, no. 2, pp. 247 2732004.

[41] D. A. Kolb, Experiential learning: Experience as the source of learning and development. Englewood Cliffs: New Jersey: Prentice-Hall Englewood Cliffs, NJ, 1984.

[42] J. Dewey, Experience and education. New York: Macmillan, 1938.

[43] A. Bandura, Social learning theory. New York: General Learning Press, 1977.

[44] L. S. Vygotsky, Ed. "Mind in society: The development of higher psychological processes." Harvard university press, 1978.

[45] K. A. Bruffee, "Collaborative learning and the" conversation of mankind"," College English, pp. 635652, 1984.

[46] J. Lave and E. Wenger, Situated learning: Legitimate peripheral participation. Cambridge university press, 1991.

[47] M. Sharples, "Disruptive Devices: Mobile Technology for Conversational Learning," Continuing Engineering Education and Life Long Learning, vol. 12, no. 5-6, pp. 310-323, 2005.

[48] G. Pask, "Styles and strategies of learning," British journal of educational psychology, vol. 46, no. 2, pp. 128-148, 1976.

[49] G. Pask, "Conversation, cognition and learning," 1975.

[50] G. Vavoula, M. Sharples, P. Rudman, J. Meek, and P. Lonsdale, "Myartspace: Design and evaluation of support for learning with multimedia phones between classrooms and museums," Computers \& Education, vol. 53, no. 2, pp. 286-299, 2009.

[51] T. Hall and L. Bannon, "Designing ubiquitous computing to enhance children's learning in museums," Journal of Computer Assisted Learning, vol. 22, no. 4, pp. 231-243, 2006.

[52] C. Van Aart, B. Wielinga, and W. R. Van Hage, "Mobile cultural heritage guide: location-aware semantic search," in Knowledge engineering and management by the masses: Springer, 2010, pp. 257-271. 
[53] V. Vlahakis et al., "Archeoguide: first results of an augmented reality, mobile computing system in cultural heritage sites," in Virtual Reality, Archeology, and Cultural Heritage, 2001, pp. 131-140.

[54] Y. Suh, C. Shin, and W. Woo, "A mobile phone guide: spatial, personal, and social experience for cultural heritage," Consumer Electronics, IEEE Transactions on, vol. 55, no. 4, pp. 2356-2364, 2009.

[55] D.-J. Park, S.-H. Hwang, A.-R. Kim, and B.-M. Chang, "A context-aware smart tourist guide application for an old palace," in Convergence Information Technology, 2007. International Conference on, 2007: IEEE, pp. 89-94.

[56] M. Angelaccio, A. Basili, B. Buttarazzi, and W. Liguori, "Smart and mobile access to cultural heritage resources: A case study on ancient Italian renaissance villas," in Enabling Technologies: Infrastructure for Collaborative Enterprises (WETICE), 2012 IEEE 21st International Workshop on, 2012: IEEE, pp. 310-314.

[57] G. Vavoula, "KLeOS: A Knowledge and Learning Organisation System in Support of lifelong Learning," PhD unpublished, Department of Electronic, Electrical andComputer Engineering, University of Birmingham, 2003.

[58] A. Bagnasco, M. Chirico, G. Parodi, and A. M. Scapolla, "A model for an open and flexible e-training platform to encourage companies' learning culture and meet employees' learning needs," Journal of Educational technology \& society, vol. 6, no. 1, pp. 55-63, 2003.

[59] L. Pemberton, S. Fallahkhair, and J. Masthoff, "Towards a Theoretical Framework for Informal Language Learning Via Interactive Television," in International Conference Cognition and Exploratory Learning in Digital Age (CELDA), 2004, pp. 27-34.

[60] L. Li, Y. Zheng, H. Ogata, and Y. Yano, "A Conceptual Framework Of Computer-Supported Ubiquitous Learning Environment," presented at the International Conference on Web-based Education (IASTED), Grindlewald: Switzerland, 2005.

[61] G. Zhang, Q. Jin, and M. Lin, "A framework of social interaction support for ubiquitous learning," in Advanced Information Networking and Applications, 2005. AINA 2005. 19th International Conference on, 2005, vol. 2: IEEE, pp. 639-643.

[62] J. Taylor, M. Sharples, C. O’Malley, G. Vavoula, and J. Waycott, "Towards a Task Model for Mobile Learning: a Dialectical Approach," International Journal of Learning Technology vol. 2, no. 2-3, pp. 138-158 2006.

[63] C. P. Nino, J. Marques, D. N. F. Barbosa, C. F. R. Geyer, J. L. V. Barbosa, and I. Augustin, "Contextaware model in a ubiquitous learning environment," in Pervasive Computing and Communications Workshops, 2007. PerCom Workshops' 07. Fifth Annual IEEE International Conference on, 2007: IEEE, pp. 182-186.

[64] T. De Jong, M. Specht, and R. Koper, "A reference model for mobile social software for learning," Int. J. Cont. Engineering Education and Lifelong Learning, vol. 18, no. 1, pp. 118-138, 2008.

[65] A. Z. Saccol, M. Kich, E. Schlemmer, N. Reinhard, J. L. Barbosa, and R. Hahn, "A framework for the design of ubiquitous learning applications," in System Sciences, 2009. HICSS'09. 42nd Hawaii International Conference on, 2009: IEEE, pp. 1-10.

[66] M. A. Chatti, M. Jarke, and M. Specht, "The 3P learning model," Journal of Educational Technology \& Society, vol. 13, no. 4, pp. 74-85, 2010.

[67] J. L. V. Barbosa, R. M. Hahn, D. N. F. Barbosa, and A. I. d. C. Z. Saccol, "A ubiquitous learning model focused on learner interaction," International Journal of Learning Technology, vol. 6, no. 1, pp. 62-83, 2011.

[68] H. Park, A. Yoon, and H.-C. Kwon, "Task Model and Task Ontology for Intelligent Tourist Information Service," International Journal of U-\& E-Service, Science \& Technology, vol. 5, no. 2, pp. 43-57, 2012.

[69] H. Candello, "Design for Outdoor Mobile Multimedia: representation, content and interactivity for mobile tourist guides," PhD, Brighton, 2012.

[70] C. Yin, Y. Song, Y. Tabata, H. Ogata, and G.-J. Hwang, "Developing and implementing a framework of participatory simulation for mobile learning using scaffolding," Journal of Educational Technology \& Society, vol. 16, no. 2, pp. 137-150, 2013.

[71] F. Saeed, D. M. K. N. Saher, F. Shahzad, and N. Ammer, "A Novel Framework For Interactive Mobile Applications," Science International vol. 26, no. 5, pp. 2089-2095, 2014.

[72] N. Parsazadeh, R. Ali, and M. Rezaei, "A framework for cooperative and interactive mobile learning to improve online information evaluation skills," Computers \& Education, vol. 120, pp. 75-89, 2018.

[73] M. B. Ada, "Using design-based research to develop a Mobile Learning Framework for Assessment Feedback," Research and Practice in Technology Enhanced Learning, vol. 13, no. 1, p. 3, 2018. 
[74] A. K. Aziz and F. Khoukhi, "A design requirements framework for mobile learning environment," in International Conference on Advanced Information Technology, Services and Systems, 2017: Springer, pp. 208-215.

[75] G. Casella and M. Coelho, "Augmented heritage: situating augmented reality mobile apps in cultural heritage communication," in Proceedings of the 2013 International Conference on Information Systems and Design of Communication, 2013: ACM, pp. 138-140.

[76] D. McGookin, K. Tahiroălu, T. Vaittinen, M. Kytö, B. Monastero, and J. C. Vasquez, "Exploring Seasonality in Mobile Cultural Heritage," in Proceedings of the 2017 CHI Conference on Human Factors in Computing Systems, 2017: ACM, pp. 6101-6105.

[77] D. Skarlatos et al., "Project iMARECULTURE: advanced VR, iMmersive serious games and augmented REality as tools to raise awareness and access to European underwater CULTURal heritagE," in EuroMediterranean Conference, 2016: Springer, pp. 805-813.

[78] M. Sharples, N. Jeffery, J. Du Boulay, D. Teather, B. Teather, and G. Du Boulay, "Socio-cognitive engineering: a methodology for the design of human-centred technology," European Journal of Operational Research, vol. 136, no. 2, pp. 310-323, 2002.

[79] J. W. Creswell, M. L. Gutmann, and W. E. Hanson, "Advanced mixed methods research designs," in Handbook of mixed methods in social and behavioral research. Thousands Oaks CA: Sage, 2003, pp. 209-240.

[80] J. W. Creswell, Research design (Qualitative, quantitative and mixed methods approaches). Sage publications., 2003.

[81] J. W. Creswell, Designing and conducting mixed methods research. Los Angeles: SAGE, 2007.

[82] J. Kitzinger, "Introducing focus groups," BMJ, vol. 311, pp. 299-302, 1995.

[83] V. Barnett, Sample survey principles and methods. Edward Arnold London, 1991.

[84] P. Greasley, Quantitative data analysis using SPSS: An introduction for health \& social science. McGraw-Hill Education (UK), 2007.

[85] R. Riding and S. Rayner, Cognitive styles and learning strategies: Understanding style differences in learning and behavior. Routledge, 1999.

[86] E. Kaasinen, "User needs for location-aware mobile services," Personal and ubiquitous computing, vol. 7, no. 1, pp. 70-79., 2003.

[87] M. Barak and A. Levenberg, "Flexible thinking in learning: An individual differences measure for learning in technology-enhanced environments," Computers \& Education, vol. 99, pp. 39-52, 2016.

[88] A. Tough, The Adult's Learning Projects. A Fresh Approach to Theory and Practice in Adult Learning. Austin, Texas Learning Concepts, 1979.

[89] G. Falloon, "Using simulations to teach young students science concepts: An Experiential Learning theoretical analysis," Computers \& Education, vol. 135, pp. 138-159, 2019.

[90] D. Laurillard et al., "A constructionist learning environment for teachers to model learning designs," Journal of Computer Assisted Learning, vol. 29, no. 1, pp. 15-30, 2013.

[91] R. R. Schmeck, Learning strategies and learning styles. Springer Science \& Business Media, 1988.

[92] N. Savio and J. Braiterman, "Design sketch: The context of mobile interaction," in Mobile HCI 2007, Singapore, 2007, pp. 284-286.

[93] M. K. Bekele and E. Champion, "A Comparison of Immersive Realities and Interaction Methods: Cultural Learning in Virtual Heritage," Frontiers in Robotics and AI, vol. 6, p. 91, 2019.

[94] G. Vavoula and M. Sharples, "Requirements for the design of lifelong learning organisers," in MLearn 2002: Proceedings of the European Workshop on Mobile and Contextual Learning, Birmingham, 2002, pp. 20-21.

[95] C. Neustaedter, J. Procyk, A. Chua, A. Forghani, and C. Pang, "Mobile video conferencing for sharing outdoor leisure activities over distance," Human-Computer Interaction, vol. 35, no. 2, pp. 103-142, 2020.

[96] N. Winters and S. Price, "Mobile HCI and the learning context: an exploration," in Proceedings of Context in Mobile HCI Workshop at MobileHCI05, 2005, pp. 19-22.

[97] J. Dillon et al., "The value of outdoor learning: evidence from research in the UK and elsewhere," School science review, vol. 87, no. 320, pp. 107-113, 2006.

[98] BBC. (2015). British Museum offers virtual reality tour of Bronze Age [Online]. Available: http://www.bbc.co.uk/news/technology-33772694.

[99] S. Rodriguez Garzon and B. Deva, "Geofencing 2.0: taking location-based notifications to the next level," in Proceedings of the 2014 ACM International Joint Conference on Pervasive and Ubiquitous Computing, 2014: ACM, pp. 921-932. 
[100] H. Candello, "Developing Principles for Outdoor Mobile Multimedia Guide in Culture Heritage Settings," in MoileHCI'09, Germany, 2009: ACM, p. 96.

[101] S. Fallahkhair, "Development Of A Cross Platform Support System For Language Learners Via Interactive Television And Mobile Phone," PhD, Brighton, 2009. 